See discussions, stats, and author profiles for this publication at: https://www.researchgate.net/publication/233534345

\title{
Measuring Autonomy Support in University Students: the Spanish Version of the Learning Climate Questionnaire
}

Article in The Spanish Journal of Psychology · November 2012

DOI: 10.5209/rev_SJOP.2012.v15.n3.39430 · Source: PubMed

\section{CITATIONS}

28

4 authors:

Juan L Núñez

Universidad de Las Palmas de Gran Canaria

145 PUBLICATIONS 1,547 CITATIONS

SEE PROFILE

Fernando Grijalvo

Universidad de Las Palmas de Gran Canaria

32 PUBLICATIONS 551 CITATIONS

SEE PROFILE
READS

548

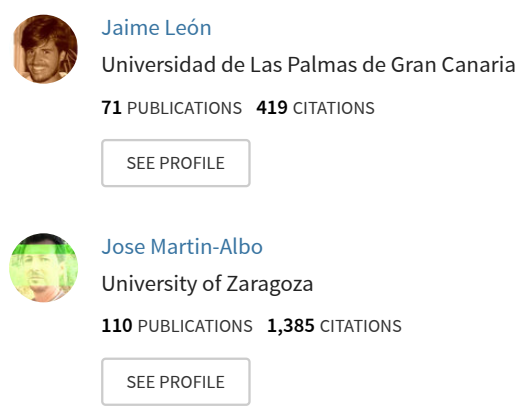

Some of the authors of this publication are also working on these related projects:

Project Body Image and Exercise in Adolescence: A Longitudinal Study View project

Project Psicología de la persona sin hogar: estilos de apego y autodeterminacion View project 


\title{
Measuring Autonomy Support in University Students: the Spanish Version of the Learning Climate Questionnaire
}

\author{
Juan L. Núñez ${ }^{1}$, Jaime León ${ }^{1}$, Fernando Grijalvo ${ }^{1}$, and José Martín Albo ${ }^{2}$ \\ ${ }^{1}$ Universidad de Las Palmas de Gran Canaria (Spain) \\ ${ }^{2}$ Universidad de Zaragoza (Spain)
}

\begin{abstract}
The goals of this research were to translate and analyze the psychometric properties of the Learning Climate Questionnaire (LCQ) and to develop a short form. The LCQ is a 15-item selfreport measure that assesses autonomy support in educational settings. A total of 422 students (60 men and 362 women) took part in this study. Results showed evidence of construct validity and adequate reliability for the LCQ. The short form consists of five items that showed sound psychometric properties. Results of Pearson correlation and Gower index showed high agreement between the long and short forms. In conclusion, both forms can be considered as preliminary versions of the original questionnaire to assess autonomy support in educational settings.

Keywords: self-determination, autonomy support, education.
\end{abstract}

\begin{abstract}
Los objetivos de este trabajo fueron traducir al español, analizar las propiedades psicométricas del Learning Climate Questionnaire (LCQ) y desarrollar una forma corta. EI LCQ es un cuestionario de 15 items que evalúa el apoyo a la autonomía en el contexto educativo. Los participantes fueron 422 estudiantes (60 hombres y 362 mujeres). Los resultados mostraron evidencias de validez de constructo y una fiabilidad adecuada. La forma corta del LCQ que consta de cinco items mostró adecuadas propiedades psicométricas. Los resultados de la correlación de Pearson y del índice Gower mostraron una alta concordancia entre las formas larga y corta. En conclusión, ambas formas pueden ser consideradas como versiones preliminares del cuestionario original para evaluar el apoyo a la autonomía en el contexto educativo.

Palabras clave: autodeterminación, apoyo a la autonomía, educación.
\end{abstract}

This research was funded by the next two grants: Agencia Canaria de Investigación, Innovación y Sociedad de la Información del Gobierno de Canarias (Project ID201000032), and Vicerrectorado I+D+I de la Universidad de Las Palmas de Gran Canaria (Project ULPGC2010-001).

Corresponding concerning this article should be addressed to Juan L. Núñez. Departamento de Psicología y Sociología, Universidad de Las Palmas de Gran Canaria. C/. Santa Juana de Arco, 1. 35004. Las Palmas (Spain). Phone: +34-928458924. E-mail: jnunez@dps.ulpgc.es 
Students usually show different attitudes in the classroom. Sometimes they may be active and cooperative, and sometimes they may adopt passive and reluctant attitudes. One of the explanations for this is that students' behaviors vary depending on social factors such us teachers' attitudes (Reeve, 2006).

\section{Influence of the context on students' motivation}

Deci (1971) established that the nature of the feedback influences the interest in an activity. If the feedback is economic, interest diminishes; however, if the reinforcement is informative, the interest in the activity increases. These results were explained via Cognitive Evaluation Theory (CET), showing that subjects with more interest in the activity had higher intrinsic motivation, defined as engaging in an activity because of the pleasure and satisfaction derived from the activity per se (Deci, 1975). For example, a student is intrinsically motivated if he studies just for the pleasure of learning.

CET was later integrated as a sub-theory within the framework of Self Determination Theory (Deci \& Ryan, 1985), which focuses on the determinants of intrinsic motivation. This theory is concerned with the conditions that facilitate versus diminish intrinsic motivation.

This theory posits that experiences that fulfill the feelings of autonomy and competence enhance intrinsic motivation, whereas events that reduce these feelings lessen intrinsic motivation. Both autonomy and competence are experiences that are completely determined by the social environment (Ryan, William, Patrick, \& Deci, 2009). One of the most important and most studied social factors that enhance intrinsic motivation is autonomy support (Deci \& Ryan, 1991).

\section{Autonomy support}

Hackman and Oldham (1975) conceived autonomy support as one of the six dimensions that explain how job characteristics influence the motivation of workers, and defined it as the opportunity for freedom, independence and discretion.

According to Deci and Ryan (1985), an essential aspect teachers should take into account in their activity is the importance of supporting students' autonomy. A context of autonomy support is one that allows students to choose between different options, minimizing the pressure to perform work of a specific way and encouraging students' own initiative. Students in classrooms with autonomysupportive teachers, as compared with those with controlling teachers (i.e. providing controlling, punishment or evaluative contingencies), will be better understood, and the teacher will accept decisions from his students instead of directing their way of thinking, as well as will offer choices and use a non-controlled and informative feedback (Deci, Connell, \& Ryan, 1989).
Some studies have shown that the teacher's attitude, autonomous versus controlling, is stable throughout the academic year (Deci, Schwartz, Scheinman, \& Ryan, 1981), and that, in classrooms where the teacher supports students' autonomy, there have been reports of increased academic performance (Flink, Boggiano, \& Barrett, 1990), greater perceived competence (Williams, Wiener, Markakis, Reeve, \& Deci, 1994) and even greater creativity (Koestner, Ryan, Bernieri, \& Holt, 1984). It is necessary to highlight that the fact that the teacher adopts an autonomy-supportive style is not enough; it is also necessary that students perceive that the teacher supports their autonomy (Hagger et al., 2007).

\section{Measures of autonomy support}

Autonomy support has been assessed in various contexts. In the health field, Williams, Grow, Freedman, Ryan, and Deci (1996) developed the Health-Care Climate Questionnaire; at work settings, Baard, Deci, and Ryan (2004) used the Work Climate Questionnaire; in team sports, Deci and Ryan developed the Sport Climate Questionnaire (SDT Web site: http://www.psych.rochester.edu/SDT/), recently translated into Spanish by Balaguer, Castillo, Tomás, and Duda (2009). Hagger et al. (2007) developed another instrument called the Perceived Autonomy Support Scale for Exercise Settings, translated into Spanish and validated in the sport context by León, Núñez, Domínguez, Martín, and Martín-Albo (2012).

Finally, in educational settings, Williams and Deci (1996) developed the Learning Climate Questionnaire (LCQ), to assess whether 181 university students felt that teachers supported their autonomy. The LCQ was adapted from the Health-Care Climate Questionnaire (Williams et al., 1996). The questionnaire consists of 15 items with a single factor structure that reflects the degree in which the students perceive that their teachers support their autonomy. All items loaded .66 or higher on the single factor. The alpha reliability of the scale was .96 .

Black and Deci (2000), with a sample of 289 university students, conducted a principal components factor analysis with varimax rotations and the results yielded a single-factor solution. Recently, Ntoumanis (2005) used a short version of the LCQ (6 items) in a sample of 460 British 15-year-old school students to analyze whether contextual and personal motivational variables could predict students' cognitive and affective experiences in school-level physical education.

\section{Objectives}

Due to the absence of a scale in Spanish to assess the perceived autonomy support in an educational context, the goals of this research were to translate and analyze the psychometric properties of LCQ, and to develop a short form of the scale, because we believe it would simplify the evaluation and analysis of the data. 
Method

\section{Participants}

A total of 422 students (60 men and 362 women) took part in this study, belonging to seven degrees taught at the Universidad de Las Palmas de Gran Canaria. The age range was between 18 and 53, with a mean age of 22.04 years and a standard deviation of 5.34. The sampling was by conglomerates where the unit of analysis was the classroom.

To assess the temporal stability, a sample of 293 students ( 35 male and 256 female), with a mean age of 21.56 years $(S D=4.75)$, completed the scale again after an interval of four weeks.

\section{Instruments}

Autonomy support. To measure this construct, the Learning Climate Questionnaire was translated into Spanish by using the procedure recommended by Hambleton (1996). Thus, items were translated from English into Spanish and, subsequently, back translated into English and compared to the original. Then the items were submitted for evaluation by three experts who considered the adequacy of items to construct. The questionnaire consists of 15 items answered on a Likert scale of 7 points from 1 (strongly disagree) to 7 (strongly agree), with an intermediate score of 4 (moderately agree).

Intrinsic motivation. To measure this construct, 12 items belonging to the intrinsic motivation factor of the Academic Motivation Scale (Núñez, Martín-Albo, \& Navarro, 2005) were used. These consisted of four items for each of the types of intrinsic motivation: intrinsic motivation to know (i.e. "because for me it is a pleasure and a satisfaction to learn new things"), intrinsic motivation to achieve (i.e. "the satisfaction I feel when I get over my studies") and intrinsic motivation to stimulating experiences (i.e. "For the intense feelings I experience when I am communicating my own ideas to others "). All items answer the question "Why do you go to college?", and are scored according to a Likert scale of seven points from 1 (does not correspond at all) to 7 (corresponds exactly) with an intermediate score of 4 (moderately matches).

Autonomy. To measure this construct, we used the subscale autonomy from the Psychological Needs Satisfaction Scale in Education (León, Domínguez, Núñez, Pérez, \& Martín-Albo, 2011). It consists of five items (e.g. "I have the feeling of doing things right") to measure three dimensions: perceived autonomy, perceived competence and perception of relationship. Responses were evaluated according to a Likert scale from 1 (strongly disagree) to 5 (strongly agree) points.

\section{Procedure}

Once the classrooms were selected, we contacted the dean to apply for permission and explain the project.
Once in the classroom, we explained the reasons for the study to the students. They also were informed that participation was voluntary and confidential, to avoid the possible effect of social desirability, and at the same time, we requested their cooperation and urged them to respond to questionnaires as honestly as possible. A researcher was present during all the applications of the instruments, and provided students with the help they needed to successfully complete the questionnaire when it was required.

\section{Data analysis}

To analyze the evidence of the questionnaire's construct validity, we conducted a confirmatory factor analysis (CFA) following the recommendation of Jackson, Gillaspy, and Purc-Stephenson (2009). To determine the evidence of reliability, we used an estimate of internal consistency, Cronbach's alpha, and an estimate of temporal stability, the test-retest Pearson correlation.

The estimation method used in the CFA was maximum likelihood. Due to the high multivariate nonnormality, we used Satorra-Bentler (S-B) robust corrections. The fit indices used were the following: the SB $\chi^{2}$ test, root mean square error of Approximation (RMSEA) and its $90 \%$ confidence interval, Tucker Lewis Index (TLI), comparative fit index (CFI) and the Standardized root mean square residual (SRMR). To perform this analysis, we used statistical software Mplus 6.1 (Muthén \& Muthén, 1998-2010) and PASW 18.

Following Marsh, Martin and Jackson (2010) recommendations to select items of a shorter version, we considered factor loadings, corrected item-test correlation, Cronbach alpha and the theoretical importance of the items. After completing this step, we proceeded to test the construct validity of the short form. Then, to evaluate the agreement of both versions, we calculated the total score of the subjects. Due to the fact that Pearson correlation only takes the monocity between both forms into account, agreement should be also measured via Gower index (Barrett, 2010). Also, it is important to compare predictive accuracy of the short and the long form score (Stanton, Sinar, Balzar, \& Smith, 2002). Thus, Pearson correlations were estimated between these two forms, intrinsic motivation and perceived autonomy, due to the relationships these two constructs have shown in other studies with autonomy support (Almagro, Sáenz-López, \& Moreno, 2010). The Pearson correlations were estimated via PASW 18 and the index with the Gower software (Barrett, 2010).

As for the lost data, it should be noted that there was less than $1 \%$. Yet, to estimate the value of these data as a precaution, we used the expectation-maximization algorithm. 
Results

\section{Descriptive Analysis}

Table 1 presents descriptive statistics (mean, standard deviation, skewness and kurtosis) of the LCQ, means ranged between 5.78 (item 5) and 2.60 (item 13) and standard deviations between 1.71 (item 10) and 1.20 (item 5). As noted, all skewness and kurtosis values are below the value 1. The Mardia coefficient for the long form was 64.54 and for the short form 7.87 .

\section{Psychometric properties of the long form}

Confirmatory factor analysis

The fit indices obtained were the following: S-B $\chi^{2}=$ $387.09(d f=90, N=422, p=.01)$, RMSEA $=.08($ CI $90 \%$ $=.07, .09), \mathrm{TLI}=.94, \mathrm{CFI}=.92, \mathrm{SRMR}=.04$. Moreover, the factor loadings values were above .65 .

\section{Reliability analysis}

The internal consistency of LCQ was measured using Cronbach alpha. The results showed a value of $(\alpha=.95)$. Regarding the temporal stability, test-retest correlation was .71.

\section{Psychometric properties of the short form} Choosing the items

Following the recommendations of Marsh et al. (2010), we selected the items $4,8,11,13$ and 14 from the long form. Table 1 display that the chosen items showed the highest factor loadings and corrected item-test correlation values. Besides, the deletion of any of these items did not affect the reliability of the scale.

\section{Confirmatory factor analysis}

The fit indices obtained were as follows: S-B $\chi^{2}=26.41$ $(d f=5, N=422, p=.01)$, RMSEA $=.10($ CI $90 \%=.06$, $.14), \mathrm{TLI}=.96, \mathrm{CFI}=.98, \mathrm{SRMR}=.02$. The factor loadings values were above .79 .

\section{Reliability}

Internal consistency of the short form measured by Cronbach's alpha was .91, and the 4-week test-retest reliability coefficients for the short form demonstrate favorable reliability $(r=.66)$

\section{Convergent and discriminant validity}

To assess the convergent validity of both forms, we followed the recommendation by Barrett (2010) and

Table 1

Descriptive statistics, factor loadings and item-test corrected correlation

\begin{tabular}{|c|c|c|c|c|c|c|}
\hline Items & $M$ & $S D$ & Skewness & Kurtosis & $\begin{array}{l}\text { Factor } \\
\text { loading }\end{array}$ & $\begin{array}{l}\text { item }- \\
\text { test } r\end{array}$ \\
\hline 1. Mi profesor/a me ofrece opciones y me permite elegir. & 5.27 & 1.30 & -.31 & -.65 & .70 & .69 \\
\hline 2. Siento que mi profesor/a me comprende. & 5.12 & 1.42 & -.40 & -.48 & .79 & .77 \\
\hline $\begin{array}{l}\text { 3. Durante las clases puedo comportarme de forma abierta } \\
\text { con mi profesor/a. }\end{array}$ & 5.55 & 1.31 & -.70 & -.17 & .70 & .68 \\
\hline $\begin{array}{l}\text { 4. Mi profesor/a me transmite confianza para hacer las cosas bien } \\
\text { en la asignatura. }\end{array}$ & 5.67 & 1.28 & -.83 & .07 & .81 & .79 \\
\hline 5. Siento que mi profesor/a me acepta. & 5.82 & 1.25 & -.96 & .45 & .77 & .75 \\
\hline \multicolumn{7}{|l|}{ 6. Mi profesor/a se asegura de que realmente entiendo los objetivos } \\
\hline de la asignatura y de lo que tengo que hacer para lograrlos. & 5.54 & 1.29 & -.64 & -.34 & .75 & .73 \\
\hline 7. Mi profesor/a me anima a hacer preguntas. & 5.55 & 1.26 & -.68 & -.22 & .66 & .64 \\
\hline 8. Confío mucho en mi profesor/a. & 4.94 & 1.48 & -.39 & -.53 & .81 & .79 \\
\hline 9. Mi profesor/a responde a mis preguntas de forma atenta y detallada. & 5.71 & 1.30 & -.96 & .47 & .78 & .75 \\
\hline 10. Mi profesor/a tiene en cuenta cómo me gustaría hacer las cosas. & 4.91 & 1.39 & -.36 & -.56 & .79 & .78 \\
\hline 11. Mi profesor/a maneja muy bien las emociones de las personas. & 5.13 & 1.41 & -.43 & -.58 & .81 & .79 \\
\hline 12. Noto que mi profesor/a se preocupa por mí como persona. & 4.53 & 1.45 & -.23 & -.38 & .77 & .76 \\
\hline 13. Me siento muy bien con la forma en que mi profesor/a me habla. & 5.58 & 1.37 & -.89 & .35 & .83 & .80 \\
\hline $\begin{array}{l}\text { 14. Mi profesor/a intenta comprender mi punto de vista antes de } \\
\text { explicarme una nueva forma de hacer las cosas. }\end{array}$ & 5.26 & 1.37 & -.48 & -.51 & .82 & .80 \\
\hline 15. Siento que puedo hablar de mis sentimientos con mi profesor/a. & 3.80 & 1.70 & .02 & -.81 & .69 & .68 \\
\hline
\end{tabular}

[Translator's note: the items have not been translated because it is the Spanish version of the scale.] 
Table 2

Pearson correlations between long form, short form, intrinsic motivation, and autonomy

\begin{tabular}{|c|c|c|c|c|}
\hline & 1 & 2 & 3 & 4 \\
\hline 1. Long form & - & & & \\
\hline 2. Short form & .96 & - & & \\
\hline 3. Intrinsic motivation & .21 & .21 & - & \\
\hline 4. Autonomy & .57 & .52 & .25 & 一 \\
\hline
\end{tabular}

Note. All correlations were significant $(p<.01)$.

conducted Pearson correlation between the total scores (long and short form) and the Gower index. As can be seen in Table 2, the correlation was .96. The Gower index was .95.

To assess the discriminant validity, we took into account the suggestions by Stanton et al. (2002) to analyze the correlations between the long and the short forms with intrinsic motivation and autonomy. Table 2 shows that the correlations between the long form and intrinsic motivation $(r=.21)$ and autonomy $(r=.57)$ were similar to the correlations between the short form and intrinsic motivation $(r=.21)$ and autonomy $(r=.52)$.

\section{Discussion}

The perception of autonomy support for students has proven to be an essential element for well-being and performance. However, we do not have an instrument in Spanish to assess autonomy support in the classroom. Thus, this study addresses two goals: first, to translate LCQ into Spanish and analyze its psychometric properties, and, second, to develop a short form of the scale.

To achieve the first objective, the translation of the questionnaire into Spanish was done following the recommendations of Hambleton (1996), in line with previous translations connected with some self-determination theory constructs (Martín-Albo, Núñez, \& Navarro, 2009; Núñez, Martín-Albo, \& Domínguez, 2010; Núñez et al., 2005). The results showed that the Spanish version presented evidence of validity and reliability.

With regard to the construct validity, we analyzed the factor structure solution of LCQ via CFA. Taking into account the recommendations of Schumacker and Lomax (1996), overall, the results indicated an adequate fit to the data yielding a single factor structure, although we should take these results with caution. These results are similar to those obtained in the original version (Williams \& Deci, 1996) and the results of Black and Deci (2000) in a university students' sample.

About the reliability, the Cronbach alpha was adequate and similar to the original study (Williams \& Deci, 1996), and the test-retest correlation showed an adequate value.

The second goal of this study was to develop a short form of LCQ. To accomplish this task, we selected five items with the highest loadings and corrected item-test correlation. In addition, none of them, individually, affects the reliability of the scale. According to self-determination framework, these five items are representative of the construct assessed. In this sense, the selected items refer to a teacher who creates a climate of confidence in the classroom, is an expert in the management of emotions and is able to empathize with the students. This version of LCQ assesses autonomy support with less items than the scale used by Ntoumanis (2005). We analyzed the factor structure of the short form via CFA. Results indicated an adequate fit to the data, which support the construct validity. Moreover, the short form developed in this study had good reliability according to estimations by Cronbach's alpha coefficient, although we can not consider optimal the result of the testretest correlation, it is a moderate value. As pointed out by Abad, Olea, and García Ponsoda (2011), instruments like the LCQ that measure unstable aspects, it is difficult to distinguish between the instability of the perception of autonomy and lack of precision of the instrument.

To verify that the reduced scale acts as a proxy for the long scale, we calculated the agreement between the subject's scores in the two scales. Due to the fact that the Pearson correlation is only an indicator of the monocity and not of agreement per se (Barrett, 2010), we also estimated the Gower index. Results were satisfactory in both indexes. Finally, according to Stanton et al. (2002), we also considered the correlation between the scores of the long and the short forms, and two external criteria, i.e. intrinsic motivation and perceived autonomy. Correlation between the long form and both external criteria were similar to the correlations between the short form and the same criteria. For all of this, we conclude that the short form is an approximate proxy for its parent form and that this short form is more convenient and requires less effort on the part of the researcher.

\section{Limitations and future perspectives}

It is necessary to highlight some constraints in this study. Smith, McCarthy, and Anderson (2000) considered that the main problem of the short forms is that the psychometric properties of the original sample, from which the items were selected, may not be representative of the population. It 
could be interesting to conduct studies in other samples (e.g. students of colleges and schools, and students from other geographical regions). Moreover, it would be appropriate to analyze in greater detail the temporal stability of the short form using difference interval between both applications.

It should also be noted that in this study, although the scale is made up of Likert items, the true nature of the data is ordinal. We thought it was appropriate to treat the data as continuous, because this reduces the complexity of the analysis. Despite this, we took possible deviations from multivariate normality into account by using the SatorraBentler procedure.

Finally, another limitation is the high percentage of female students in this university. For this reason we were not able to analyze the scale invariance in terms of gender. Further studies should study the gender factor by using more homogeneous samples.

\section{Conclusions}

In conclusion, the results showed that the Spanish version of the LCQ presents preliminary evidence of validity and reliability, so this version may be used in a university setting to assess whether students feel that their teacher promotes their autonomy. Additionally, the second goal of this study was to develop a short version, which assesses the same construct in a very similar way, but significantly reduces the application time while maintaining sound psychometric properties to measure the autonomy support in university students.

\section{References}

Abad, F. J., Olea, J., Ponsoda, V., \& García, C. (2011). Medición en ciencias sociales y de la salud [Measurement in the social and health sciences]. Madrid, Spain: Síntesis.

Almagro, B. J., Sáenz-López, P., \& Moreno, J. A. (2010). Prediction of sport adherence through the influence of autonomy-supportive coaching among Spanish adolescent athletes. Journal of Sports Science and Medicine, 9, 8-14.

Baard, P. P., Deci, E. L., \& Ryan, R. M. (2004). Intrinsic need satisfaction: A motivational basis of performance and wellbeing in two work settings. Journal of Applied Social Psychology, 34, 2045-2068. http://dx.doi.org/10.1111/j.15591816.2004.tb02690.x

Balaguer, I., Castillo, I., Duda, J. L., \& Tomás, I. (2009). Análisis de las propiedades psicométricas de la versión española del Cuestionario de Clima en el Deporte [Analysis of the psychometric properties of the Spanish version of the Sport Climate Questionnaire]. Revista de Psicología del Deporte, 18, 73-83.

Barret, P. (2010). Gower program help file. Auckland, New Zealand: Advanced Projects R\&D Ltd.
Black, A. E., \& Deci, E. L. (2000). The effects of instructors' autonomy support and students' autonomous motivation on learning organic chemistry: A self-determination theory perspective. Science Education, 84, 740-756. http://dx.doi.org/ 10.1002/1098-237X(200011)84:6<740::AID-SCE4>3.0.CO;2-3

Deci, E. L. (1971). Effects of externally mediated rewards on intrinsic motivation. Journal of Personality and Social Psychology, 18, 105-115. http://dx.doi.org/10.1037/h0030644

Deci, E. L. (1975). Intrinsic motivation. New York, NY: Plenum.

Deci, E. L., \& Ryan, R. M. (1985). Intrinsic motivation and selfdetermination in human behavior. New York, NY: Plenum Press.

Deci, E. L., \& Ryan, R. M. (1991). A motivational approach to self: Integration in personality. In R. Dienstbier (Ed.), Nebraska Symposium on motivation: Vol. 38. Perspectives on motivation (pp. 237-288). Lincoln, NE: University of Nebraska Press.

Deci, E. L., Connell, J. P., \& Ryan, R. M. (1989). Selfdetermination in a work organization. Journal of Applied Psychology, 74, 580-590. http://dx.doi.org/10.1037//00219010.74.4.580

Deci, E. L., Schwartz, A., Scheinman, L., \& Ryan, R. M. (1981). An instrument to assess adult's orientations toward control versus autonomy in children: Reflections on intrinsic motivation and perceived competence. Journal of Educational Psychology, 73, 642-650. http://dx.doi.org/10.1037//00220663.73.5.642

Flink, C., Boggiano, A. K., \& Barrett, M. (1990). Controlling teaching strategies: Undermining children's self-determination and performance. Journal of Personality and Social Psychology, 59, 916-924. http://dx.doi.org/10.1037//00223514.59.5.916

Hackman, J. R., \& Oldham, G. R. (1975). Development of the job diagnostic survey. Journal of Applied Psychology, 60, 159-170. http://dx.doi.org/10.1037/h0076546

Hagger, M. S., Chatzisarantis, N. L. D., Hein, V., Pihu, M., Soós, I., \& Karsai, I. (2007). The perceived autonomy support scale for exercise settings (PASSES): Development, validity and cross-cultural invariance in young people. Psychology of Sport and Exercise, 8, 632-653. http://dx.doi.org/10.1016/j. psychsport.2006.09.001

Hambleton, R. K. (1996). Adaptación de test para su uso en diferentes idiomas y culturas: Fuentes de error, posibles soluciones y directrices prácticas [Adaptation of tests for use in different languages and cultures: Sources of error, possible solutions and practical guidelines]. In J. Muñiz (Ed.), Psicometría (pp. 67-89). Madrid, Spain: Universitas.

Jackson, D. L., Gillaspy, J. A., \& Purc-Stephenson, R. (2009). Reporting practices in confirmatory factor analysis: An overview and some recommendations. Psychological Methods, 14, 6-23. http://dx.doi.org/10.1037/a0014694

Koestner, R., Ryan, R. M., Bernieri, F., \& Holt, K. (1984). Setting limits on children's behavior: The differential effects of controlling versus informational styles on intrinsic motivation and creativity. Journal of Personality, 52, 233-248. http://dx.doi.org/10.1111/j.1467-6494.1984.tb00879.x 
León, J., Domínguez, E., Núñez, J. L., Pérez, A., \& Martín-Albo, J. (2011). Traducción y validación de la versión española de la Échelle de Satisfacción des Besoins Psychologiques en el contexto educativo [Translation and validation of the Spanish version of the Échelle de Satisfaction des Besoins Psychologiques in academic context]. Anales de Psicología, 27, 405-411.

León, J., Núñez, J. L., Domínguez, E., Martín, P., \& Martín-Albo, J. (2012). Traducción y validación de la versión española de la Échelle des Perceptions du Soutien à l'Autonomie en Sport [Translation and validation of the Spanish versión of the Échelle des Perceptions du Soutien à l'Autonomie en Sport]. Universitas Psychologica, 11, 165-175.

Marsh, H., Martin, A., \& Jackson, S. (2010). Introducing a short version of the Physical Self Description Questionnaire: New strategies, short-form evaluative criteria, and applications of factor analyses. Journal of Sport and Exercise Psychology, 32, 438-482.

Martín-Albo, J., Núñez, J. L., \& Navarro, J. G. (2009). Validation of the Spanish version of the Situational Motivation Scale (EMSI) in the educational context. The Spanish Journal of Psychology, 12, 799-807.

Muthén, L. K., \& Muthén, B O. (1998-2010). Mplus User's Guide. Sixth Edition. Los Angeles, CA: Muthén \& Muthén.

Ntoumanis, N. (2005). A prospective study of participation in optional school physical education using a self-determination theory framework. Journal of Educational Psychology, 97, 444-453. http://dx.doi.org/10.1037/0022-0663.97.3.444

Núñez, J. L., Martín-Albo, J., \& Domínguez, E. (2010). Propiedades psicométricas de la Escala de Satisfacción con la Vida en sujetos practicantes de actividad física [Psychometric properties of the Satisfaction with Life Scale in physical activity practitioners]. Revista de Psicología del Deporte, 19, 291-304.

Núñez, J. L., Martín-Albo, J., \& Navarro, J. G. (2005). Validación de la versión española de la Échelle de Motivation en Éducation [Validity of the Spanish versión of the Échelle de Motivation en Éducation]. Psicothema, 17, 344-349.
Reeve, J. (2006). Teachers as facilitators: What autonomysupportive teachers do and why their students benefit. The Elementary School Journal, 106, 225-236. http://dx.doi.org/ $10.1086 / 501484$

Ryan, R. M., Williams, G. C., Patrick, H., \& Deci, E. L. (2009). Self-determination theory and physical activity: The dynamics of motivation in development and wellness. Hellenic Journal of Psychology, 6, 107-124.

Shumacker, R. E., \& Lomax, R. G. (1996). A beginner's guide to structural equation modeling. Mahwah, NJ: Erlbaum.

Smith, G. T., McCarthy, D. M., \& Anderson, K. G. (2000). On the sins of short form development. Psychological Assessment, 12, 102-111. http://dx.doi.org/10.1037//1040-3590.12.1.102

Stanton, J. M., Sinar, E. F., Balzer, W. K., \& Smith, P. C. (2002). Issues and strategies for reducing the length of self-report scales. Personnel Psychology, 55, 167-194. http://dx.doi.org/ 10.1111/j.1744-6570.2002.tb00108.x

Williams, G. C., \& Deci, E. L. (1996). Internalization of biopsychosocial values by medical students: A test of selfdetermination theory. Journal of Personality and Social Psychology, 70, 767-779. http://dx.doi.org/10.1037//00223514.70.4.767

Williams, G. C., Grow, V. M., Freedman, Z., Ryan, R. M., \& Deci, E. L. (1996). Motivational predictors of weight loss and weight-loss maintenance. Journal of Personality and Social Psychology, 70, 115-126. http://dx.doi.org/10.1037//00223514.70.1.115

Williams, G. C., Wiener, M. W., Markakis, K. M., Reeve, J., \& Deci, E. L. (1994). Medical students'motivation for internal medicine. Journal of General Internal Medicine, 9, 327-333. http://dx.doi.org/10.1007/BF02599180

Received May 13, 2011 Revision received August 8, 2011 Accepted September 15, 2011 